\title{
PARAPLEGIA IN WOMEN
}

\author{
By Jerzy Kiwerski, M.D. ${ }^{1}$ and Shaban H. Ahmad, M.D. \\ ${ }^{1}$ Assistant Professor, Spinal Cord Unit, Rehabilitation Institute, Konstancin, Poland.
}

Summary. In the period I965-80, I 25 women were treated because of paralysis or paresis of the lower extremities resulting from spinal trauma. In this report the causes of trauma, as well as the clinical and functional treatment of this group are discussed. The most frequent causes of trauma were falls from heights, from a tree, a ladder, a horse-cart as well as suicidal jumps and road accidents.

It was ascertained that the results of treatment of spinal cord injuries in the upper thoracic segment are worse than in its lower part. These results do not differ from men with similar degrees and neurological levels of spinal cord injury. On the other hand the duration of treatment is longer in women than in men with the same degree of spinal cord lesion, amounting on the average to $17 \cdot 4$ weeks.

Key words: Spinal Injury; Paraplegia in women; Hospitalisation time; Results of treatment.

\section{Introduction}

Traumatic inJURIES of the spinal cord are less frequent in women than in men. According to various authors they constitute from 12.6 per cent to 20 per cent of all patients suffering spinal trauma (Kurtzke, 1975; Yashon, I978; Sutton I973). This group, however, involves special social and treatment problems owing to causes connected with the care of the children, 'decreased psychological resistance', poor adaptation to disability conditions and inferior physical development, all of which slow down the results of physiotherapy. In our report we wish to present a group of women, managed in the Rehabilitation Institute at Konstancin, with paralysis or paresis of the lower extremities as a result of thoracic and lumbar spinal trauma.

\section{Clinical Material}

During the period I965-80, I 25 women were treated after spinal trauma in the $\mathrm{D}_{1}-\mathrm{L}_{4}$ segments with subsequent paralysis or paresis of the lower extremities.

The most important causes of spinal trauma and the age of the analysed group of patients is given in Table I. The most frequent cause of a spinal lesion in women is a fall from a height, as for instance, from a horse-cart or from a tree or a ladder. Quite often spinal injuries in women are caused by suicidal jumps from a height. Usually, young or middle-aged women up to 55 years of age (average being 38.8 years), are involved.

The level of the trauma and degree of spinal cord injury ascertained on admission are presented in Table II.

Incomplete nervous system injury has been divided into three degrees 
TABLE I

Aetiology of the trauma

\begin{tabular}{|c|c|c|c|c|c|c|c|}
\hline \multirow[t]{2}{*}{ Trauma caus } & & \multicolumn{5}{|c|}{ Age of patients } & \multirow[b]{2}{*}{ Total } \\
\hline & & $\begin{array}{c}\text { Up to } \\
25 \text { years }\end{array}$ & $26-40$ & $4 I-55$ & $56-70$ & $\begin{array}{c}\text { Over } \\
70\end{array}$ & \\
\hline & from a cart & - & I & 9 & 3 & I & I 4 \\
\hline Falls & from a tree & 4 & 2 & 3 & - & - & 9 \\
\hline \multirow[t]{3}{*}{ from height } & from a ladder & I & 2 & 3 & 6 & I & 13 \\
\hline & suicidal jump & 9 & 4 & 3 & 一 & - & I6 \\
\hline & other falls & 5 & 3 & 7 & 6 & 2 & 23 \\
\hline Road & automobile & 8 & 5 & 5 & - & - & I 8 \\
\hline \multirow[t]{2}{*}{ accidents } & motorcycle & 3 & I & - & - & - & 4 \\
\hline & others & 2 & 3 & 2 & I & - & 8 \\
\hline Crushing & & 4 & 3 & 2 & 2 & - & I I \\
\hline Other causes & & 4 & 3 & 2 & - & - & 9 \\
\hline Total & & 40 & 27 & 36 & I 8 & 4 & 125 \\
\hline
\end{tabular}

TABLE II

Neurological level of the spinal injury

\begin{tabular}{|c|c|c|c|c|}
\hline \multirow{3}{*}{$\begin{array}{c}\text { Level } \\
\text { of spine trauma }\end{array}$} & \multicolumn{4}{|c|}{ Injury to the nervous system } \\
\hline & \multirow[t]{2}{*}{ Complete } & \multicolumn{2}{|c|}{ Incomplete } & \multirow[t]{2}{*}{ Total } \\
\hline & & I & 2 & \\
\hline $\mathrm{D}_{1}-\mathrm{D}_{4}$ & 7 & I & 2 & IO \\
\hline $\mathrm{D}_{5}-\mathrm{D}_{8}$ & I I & 5 & 2 & I 8 \\
\hline $\mathrm{D}_{9}-\mathrm{D}_{11}$ & I 2 & 3 & 4 & I9 \\
\hline $\mathrm{D}_{12}-\mathrm{L}_{1}$ & 30 & I3 & 17 & 60 \\
\hline $\mathrm{L}_{2}$ and below & 4 & I & I3 & I 8 \\
\hline Total & 64 & 23 & 38 & I 25 \\
\hline
\end{tabular}

(Haftek et al., I968), corresponding to the classification of Frankel et al. (1969), with groups B, C and D.

I. Kinetic paralysis with slight preservation of deep sensation in the feet.

2. Severe paresis (strength of muscle groups below $3^{\circ}$ in the Lovett scale).

3. Lower degree paresis.

We limited ourselves, under the circumstances, to discussion of complete and incomplete injuries of the Ist and 2nd group, with complete injuries constituting the greater number of cases.

In the analysed group spinal injuries were most often found in the $\mathrm{D}_{12}-\mathrm{L}_{1}$ segments because of the anatomical conditions and by the fact that the thoracic segment is stable, but has considerable mobility with the lumbar spine. 


\section{Results of Treatment}

Table III presents the results of treatment, comparing neurological status in patients on admission with that recorded after treatment and taking into account the level of the spinal injury. In general (5 I per cent of cases), we obtained neurological improvement; however, distinct differences between treatment of injuries at various segments were obtained. In this respect, injuries to the high thoracic segment of the spinal cord presented the worst prognosis. In this segment improvement was recorded in only 3 I per cent of patients, especially in those admitted with symptoms of incomplete spinal cord injury. This corresponds with our earlier observations (Chrostowska et al., I978; Kiwerski et al., I980). Considerable improvement in two groups was obtained in only 8 per cent of cases. Distinctly better were the results of treatment of spinal cord injuries in the lower segment $\left(\mathrm{D}_{9}-\mathrm{L}_{1}\right)$. In $5 \mathrm{I}$ per cent and in 22 per cent of patients we obtained improvement and considerable improvement respectively.

TABLE III

Result of treatment

\begin{tabular}{lcccr}
\hline \multirow{2}{*}{$\begin{array}{c}\text { Neurological } \\
\text { status }\end{array}$} & \multicolumn{2}{c}{ Level of spine trauma } & Total \\
\cline { 2 - 4 } & $\mathrm{D}_{1}-\mathrm{D}_{8}$ & $\mathrm{D}_{9}-\mathrm{L}_{1}$ & Below $\mathrm{L}_{1}$ & \\
\hline C-3 & - & 3 & - & 3 \\
C-2 & - & 4 & 2 & 6 \\
I-3 & 2 & 7 & $\mathrm{I}$ & 10 \\
I-2 & 3 & 6 & - & 9 \\
$2-$ norm & - & 3 & 3 & 6 \\
$2-3$ & 3 & $\mathrm{I}$ & 8 & 27 \\
C-C & $\mathrm{I}$ & 32 & 2 & 50 \\
I-I & $\mathrm{I}$ & 3 & - & 4 \\
$2-2$ & $\mathrm{I}$ & 2 & 2 & 5 \\
Deaths & 2 & 3 & - & 5 \\
Total & 28 & 79 & $\mathrm{I} 8$ & I 25 \\
\hline
\end{tabular}

TABLE IV

Functional results of treatment

\begin{tabular}{|c|c|c|c|c|c|c|c|}
\hline \multirow[t]{2}{*}{ Treatment time } & \multicolumn{4}{|c|}{ Manner of locomotion } & \multirow[b]{2}{*}{ Bed } & \multirow[b]{2}{*}{ Death } & \multirow[b]{2}{*}{ Total } \\
\hline & $\begin{array}{l}\text { With } \\
\text { crutches }\end{array}$ & $\begin{array}{l}\text { With } \\
\text { a stick }\end{array}$ & Independe & t Wheelchair & & & \\
\hline up to 6 weeks & I & - & 4 & - & I & 4 & IO \\
\hline 7-12 weeks & I 2 & 3 & I 4 & I 8 & I & I & 49 \\
\hline $4-5$ months & I4 & 5 & 7 & I 5 & - & - & $4 \mathrm{I}$ \\
\hline 6-8 months & 6 & - & I & 12 & - & - & I9 \\
\hline 9-12 months & - & 2 & - & 4 & - & - & 6 \\
\hline Total & 33 & IO & 26 & 49 & 2 & 5 & 125 \\
\hline
\end{tabular}


The most promising results were obtained in the management of lesions of the lumbar spine segment, showing improvement in 78 per cent and significant improvement in 33 per cent of patients. It should be pointed out, however, that in this group there were few patients admitted with symptoms of complete paralysis. Mortality in the analysed group of patients amounted to 4 per cent.

The above results do not differ from those obtained in men with a similar degree and level of nervous system injury. Also, the control of micturation is similar in women and in men, though we are under the impression that in women the control would be slower.

Presented in Table IV are the functional effects of treatment of the discussed group in relation to the duration of hospital management. Almost half the patients completed hospitalisation in 3 months. The average stay in hospital amounted to $17 \cdot 4$ weeks, which exceeds by more than two weeks the average treatment time of patients in our department (Kiwerski and Ahmad, I982).

Worthy of notice is the fact that more than 57 per cent of patients were discharged from our hospital with the functional ability of walking, in spite of including in the above analysis patients admitted with symptoms of complete or almost complete injury of the nervous system.

\section{Conclusions}

I. Women sustained serious traumatic spine injuries in the thoracic and lumbar segments six times less frequently than did men.

2. The most frequent causes of spinal trauma in women at this level included falls from a tree, a ladder or horse-cart, also suicidal jumps from a height and automobile accidents.

3. Decidedly worse are the effects of treatment of spinal cord trauma in the upper thoracic segment than in its lower part. Those results do not differ in principle from those obtained in men with a similar level and a similar degree of nervous system damage.

4. Hospitalisation time in women is slightly longer than in men.

However, one can obtain equally good functional results as is evidenced by the fact that over 57 per cent of the patients were discharged from the hospital able to walk.

\section{RÉSUMÉ}

En le période I965-I980 on a soigné I 25 femmes avec la paralysie ou avec une parésie de membres inférieurs résultantes de trauma de la colonne vertébrale.

On a montré dans le récit les causes de la lésion, aussi les résultats neurologiques et fonctionnelles de la thérapie de cette groupe des malades.

On a constaté que les chutes de la hauteurs des arbres, des échelles, des charriots, et aussi les résultats des suicides, ou des accidents de la route font en plupart la cause des traumas.

On a constaté que le résultat du traitement des traumas de la moelle épinière du segment thoracique supérieure sont pires que celui du segment plus bas, et qu'il ne se distingue pas du résultat du traitement des hommes après le trauma du même degré et hauteur.

Par contre, le temps nécessaire pour le traitement des femmes est un peu plus longue que pourle traitement des hommes après le trauma de la moelle avec le même degré, et fait en total 17,4 semaines en moyenne. 


\section{ZUSAMMENFASSUNG}

In Folge der Wirbelsäuelebeschädigung befanden sich im Zeitraum I965-I980-I25 Frauen, mit Beinlähmung oder tiefer Beinparalese, unter ärztlicher Behandlung. Im Beitrag wurden Ursachen der Verletzungen, und funktionelle sowie neurologische Heilergebnisse dieser Krankengruppe bespochen. Verlrtzungsgrund waren meistens Abstürze: vom Baum, Leiter, Pferdewagen, Selbstmordversuche und Strassenunfälle.

Festgestellt werden konnte, dass die Heilergebnisse der Rückenmarkverletzungen im oberen Brustteil unzufriedener, als die der unteren Beschädigungen sind, wobei sie sich nicht unterscheiden von den Heilergebnissen bei den Männern mit analogischen Grad und Höhe der Rückenmarkverletzungen.

Jedoch in der Regel ist die Heilzeit bei den Frauen im Vergleich zu den Männern minimal länger, und beträgt, 17,4 Wochen.

\section{REFERENCES}

Chrostowska, T., Kiwerski, J. \& Makowski, J. (I978). Results of treatment of the dorsal spine injuries. Chir. N. Ruchu i Ortop. Polska, 43, 105.

Frankel, H. L., Hancock, D. O., Hyslop, G. \& Melzak, J. (I969). The value of postural reduction in the initial management of closed injuries of the spine. Paraplegia, 7 , p. 179 .

HAFTEK, J., RudNicki, S. \& KiWERSKI, J. (I968). Acute trauma of the cervical segment of the spinal cord. Compensation of the function of the spinal cord. PZWL, Warszawa, p. 75 .

KiWERSKI, J. \& Chrostowska, T. (I980). Remote results of treatment of the thoracic spine injuries. Chir. N. Ruchu i Ortop. Polska, 45, 7.

KIWERSKI, J. \& SHABAN H. AHMAD (I982). Factors conditioning hospitalization time of patients after spinal cord injuries. Chir. N. Ruchu i Ortop. Polska, 47, 3.

KURTZKe, J. F. (1975). Epidemiology of spinal cord injury. Exp. Neurol., 48, i63.

Sutton, N. G. (1973). Spinal Cord Injuries. Butterworth, London.

YASHON, D. (1978). Spinal Injury. Appleton-Century-Crofts, New York. 